UDC 591.463.1+612.616.2:612.014.48

\title{
DYNAMICS OF GAMMA-RADIATION DAMAGE AND RECOVERY DEVELOPMENT IN REPRODUCTIVE ORGANS AND SPERM
}

\author{
A. V. KLEPKO, PhD of Biological Sciences, Head of the Radiobiology \\ and Radioecology Department, \\ https://orcid.org/0000-0002-7061-453X \\ National University of Life and Environmental Sciences of Ukraine \\ E-mail: alla.klepko@gmail.com \\ S. V. ANDREICHENKO, Professor of Biology Department \\ https://orcid.org/0000-0002-3180-3805 \\ University of Patra, Greece \\ E-mail: sergiian@gmail.com \\ I. M. GUDKOV, Doctor of Biological Sciences, Professor of the Radiobiology \\ and Radioecology Department, \\ https://orcid.org/0000-0003-3297-6190 \\ National University of Life and Environmental Sciences of Ukraine \\ E-mail:ingudkov@ukr.net
}

https://doi.org/10.31548/bio2019.04.006

Research aimed in studying the dose-dependent dynamics of injury and recovery of male germ cells in the long term after local gamma-irradiation. Laboratory white rats in the age of 3 months were irradiated by gamma rays of $60 \mathrm{Co}$ in the dose range $1,0-18,0 \mathrm{~Gy}$ with a dose rate $1.0 \mathrm{~Gy} / \mathrm{min}$. Sperm number in testicules and epididymices was detected by phase-contrast microscopy after organ homogenization. Daily spermatozoa production by testis was calculated through dividing total number of turbulent-resistant sperm on 6.1. The experiments showed that seminiferous tubules showed dose dependent depletion of germ cell stocks inside them with simultaneous preservation of somatic Sertoli cells in sufficient abundance that was favorable for further regeneration of stem spermatogonia (As) and subsequent repopulation of tubules. Dose of $1,0 \mathrm{~Gy}$ was shown to cause no or slide detrimental effects on animal development and sperm production, while doses 7,0-12,0 Gy resulted in evident radiation damage. Dose of 18,0 Gy fully suppressed spermatogenesis and spermiogenesis.

Keywords: local irradiation, spermatogenesis, germ cells, rats, daily spermatozoa production, viability, long-term period

Introduction. About 30 years from Chornobyl accident have elapsed. A said period has enriched our knowledge about physicochemical facets of radiation and provided new insight into radiation damage from environ- mental or occupational radiation exposure on the basis of advanced molecular techniques and gene sequencing. Yet, the high pollution of numerous territories in Ukraine, Belorussia and Russian Federation by radionuclides, such as 
cesium, strontium, plutonium and americium, created unique natural conditions for observing radiation effects on different plant and animal species as well as human beings that resulted from chronic low-dose ionizing irradiation of internal or external origin and their combination too. Apart from this, a number of people who participated in liquidation of Chornobyl catastrophe were subjected to acute ionizing irradiation or long-term irradiation with relatively high dose rate. In this connection we may regard the experimental data collected in the course of Chornobyl disaster and in its aftermath as an invaluable scientific heritage which requires further thorough evaluation and analysis in collation with the results of previous investigations undertaken in consequence of atomic bombarding of Hiroshima and Nagasaki, accidents on atomic power plants in former Soviet Union and USA and the recent tragic events on Fukushima Daiichi Nuclear Power plant provoked by Great East Japan Earthquake on 11 March 2011 that caused a discharge of a tremendous amount of radioactivity in the environment and the world ocean, in particular.

Analysis of recent researches and publications. Genotoxic effects of post-Chornobyl environmental radiation pollution were studied thoroughly on house mice (Mus musculus) by Pomerantseva et al. (Pomerantseva M. D., Ramaiya L. K., Chekhovich A. V., 1997) and Goncharova together with Ryabokon (Goncharova R. I., Ryabokon N. I., 1995) - on bank vole (Clethionomys glareolus) in the investigations performed over 1986-1994. The dose rate of gamma-irradiation on the soil surface where house mice lived ranged from 0.0002 to $2 \mathrm{mGy} / \mathrm{h}$. The frequency of reciprocal translocations in mouse spermatocytes was shown to be relatively low but increased with the dose rate. Embryo mortality was of the highest value in 1987, especially in the area of the elevated radionuclide contamination where the absorbed dose on animal gonads constituted 3-4 Gy, and then gradually declined in the coming years.
Germ cells in the seminiferous epithelium are frequently regarded to be protected from chemical toxicants and radionuclides by the blood-testis barrier which is formed by tight junctions between adjacent Sertoli cells at their basolateral surfaces (Hoyes K. P., Morris I.D., 1996). However, several studies in rodents have provided the arguments in favor of possibility for some actinide radionuclides, namely plutonium, americium and polonium, to bind to serum transferrin and circumvent blood-testis barrier through natural iron-transferrin pathway (Miller S. C., Rowland H. G., Bowman B. M., 1985). Apropos, $\mathrm{Pu}$ retention half-time in animal testis may attain approximately 1 year. Further, quantitative autoradiography has demonstrated that testicular $\mathrm{Pu}$ in mice is not distributed uniformly throughout the testis but localized primarily in the lysosomal compartment of interstitial tissue macrophages and then in seminiferous tubule adluminal compartment (Preist N. D., Jackson S., 1978; Taylor D. M., 1993).

Consequently, spermatogonial stem cells should become an open target for -particle attack thereby accumulating high radiation doses. Further intratubular accumulation of $\mathrm{Pu}$ and other actinide radionuclides may subsequently create additional biological hazards to those resulted from interstitial tissue radionuclide deposits. Due to this, the induction of dominant lethal mutations through ${ }^{238} \mathrm{Pu}$ incorporated into mice was detected (Pomerantseva M. D., Ramaya L. K., Shevchenko V. A., Vilkina G. A., Lyaginskaya A. M., 1989).

${ }^{134} \mathrm{Cs}$ and ${ }^{137} \mathrm{Cs}$ which are known to emit $\gamma$ - and $\beta$-rays have contaminated the territories as in the vicinity to Chornobyl as far beyond 30-km zone. In this connection the carried out investigation on population of house mice inhabiting Chornobyl and Bryansk regions provided sound proof of caesium redundant incorporation in animal testicules (Ramaiya L. K., Pomerantseva M. D., Chekhovich A. V., Lyaginskaya A. M., Kuznetsov A. S., 1994; 
Pomerantseva M. D., Ramaiya L. K., Chekhovich A. V., 1995). In consequence, the elevated frequency of lethal recessive mutations (LRM) at T-locus arised, the latter being shown to persist in natural populations due to gamete selection leading to preservation of t-haplotype carriers (Demin J. S., Kryukov V. I., Orlov V. N., 1980). Concurrently, temporal variations of embryonic mortality in generations of house mice were observed in the course of 10 years after Chornobyl disaster. However, Yamashito et al. (Yamashiro H., Abe Y., Fukuda T., Kino Ya., Kawaguchi I., Kuwahara Yo., Fukumoto M., Takahashi S., Suzuki M., Kobayashi J., 2013) have not found any radiation-induced adverse effects on spermatogenesis in two bulls following 10-month exposure by ${ }^{134} \mathrm{Cs}$ and ${ }^{137} \mathrm{Cs}$ of both internal and external localization, with total absorbed dose by testes being 3.6-4.6 mGy for the first bull and 6.9-11.4 mGy for the second one. Such a discrepancy may have appeared either because of miserable quantity of animal experimental group or comparably low accumulated radiation doses.

The detailed examination of testicular germ cells in mouse under different radiation dose exposures revealed that incompleteness of spermatogonial stem cell post-radiation recovery and DNA repair stipulated a surge of sperm head abnormalities along with increased susceptibility to in situ DNA denaturation at doses as low as 12-25 rad. A dose of $100 \mathrm{rad}$ was necessary to invoke a raise in the relative number of diploid elongated spermatids with concomitant reduction of both S-phase cells and haploid spermatids (Sailer B. L., Jost L. K., Erikson K. R., Tajiran M. A., Evenson D. P., 1995).

Recent independent studies revealed radiation-induced mini-satellite mutations in the differentiating spermatogonia of mouse at a hypervariable mini-satellite locus transmitted sexually via paternal germline (Dubrova Y. E., Jeffreys A.J., MalashenkoA. M., 1995; Sadamoto S., Suzuki S., Kamiya K., Kominami R., Dohi K., Niwa O., 1994). In addition, the more detailed analysis of murine pedigrees demonstrated an obvious increase in germline mutations frequencies for doses between 0.5 and 3.0 Gy, a doubling dose being 0,33 Gy. Moreover, differentiating pre-meiotic spermatogonia were shown to be particularly radiosensitive compared to other germ cells (Dubrova Y. E., Plump M., Brown J., Fennelly J., Bois P., Goodhead D., Jeffreys A. J., 1998; Dubrova Y. E., Plump M., Brown J., Jeffreys A. J., 1998).

It was also shown, that destruction of the sperm plasma membrane does not affect fertilization and further development. Hence, fertilization and development can be achieved by dead spermatozoa at an early stage of necrosis when only the plasma membrane has been damaged (Ahmadi A., Ng S-Ch., 1997). However, the integrity of the genetic material influenced in vitro development of the embryos and live fetuses, the early pregnancy loss being caused by sperm DNA strand breakage abundance (Ahmadi A., Ng S-Ch., 1999).

The indirect negative effect of radiation on sperm DNA in animals was found to be caused by the production of an excess of reactive oxygen species (ROS) and significant decrease of antioxidant resources (Jensen $\mathrm{T}$. K., Bonde J. P., Joffe M., 2006). Noteworthy, relevant studies on population of barn swallows from Chornobyl region have elucidated negative correlation between sperm abnormalities and reserves of circulating and stored antioxidants, namely vitamins $\mathrm{A}$ and $\mathrm{E}$, carotenoids (Moller A. P., Surai P. F., Mousseau T. A.; 2005). Also, antioxidants were shown to protect sperm motility, the percentage of motile sperm being highest for the lowest level of radiation background and for highest level of plasma antioxidants. Conversely, slow sperm with high tail beat frequency were most frequent for relatively low levels of plasma antioxidant capacity and relatively high radiation background (Bonisoli-Alkuati A., Moller A. P., Rudolfsen G., Saino N., Caprioli M., Osterniller Sh., Mousseau T. A., 2011). These results were consistent with a documented 
reduction in hatching success of barn swallow eggs in radioactively contaminated sites and the population decline of barn swallows breeding in the region (Moller A. P., Karadas F., Mousseau T. A., 2008). It is worth mentioning, that in contrast to the Chornobyl population of birds, the abundance of barn swallow population in Fukushima region in aftermath the accident was not so severely affected (Moller A. P., Karadas F., Mousseau T. A., 2012).

In several reports (Vorobtsova I. E., 2002; Yablokov A. V., Nesterenko V. B., Nesterenko A. V., 2009) the effect of chronic irradiation of rats which had been held in cages in animal house the Chornobyl city close to Chornobyl APS was studied. The authors found out the spermatogenesis depression and partial deprivation of germinal epithelium from seminiferous tubules upon accumulation the radiation dose in the range 21-59 rad. Furthermore, the radiation effects on spermatogenesis and hormone imbalance enhanced concurrently with dose rate elevation. Apart from this, the changes in estradiol/testosterone ratio were shown to bias upward when the radiation dose increased.

Thereby a series of reports provided a valuable information concerning radiation injury of germ cell genome, spermatozoid structure and spermatogenesis disruption in animals in consequence of Chornobyl disaster due to high radionuclide pollution of the environment. However, a comprehensive evaluation of radiation damage temporal development for a wide dose range from low to moderate and sublethal values at various dose rates has not been realized since studies of human and wild animal populations are often embarrassed by difficulties in biomaterial collection, limitations in germ cell availability and insufficient dosimetry. Likely, the aforesaid arguments have been crucial for emerging controversial results in exploration of radioactive caesium effects on bull testis after Fukushima accident and Chornobyl mice (Pomerantseva M. D., Ramaiya L. K., Chekhovich A. V., 1997; Yamashiro H., Abe Y.,
Fukuda T., Kino Ya., Kawaguchi I., Kuwahara Yo., Fukumoto M., Takahashi S., Suzuki M., Kobayashi J., 2013), discovering of mini-satellite mutation inheritance in human (Furistu F., Ryo H., Yeliseeva K. G., Thuy I. T., Kawabata H., Krupnova E. V., Trusova V. D., Rzheutsky V. A., Nakajima H., Nomura T., 2005; Kodaira M., Satoh C., Hiyama K., Toyama K., 1995) and abundant leukemia induction in children living near Sheffield nuclear power plant in England (Livshits L. A , Malyarchuk S. G., Luk'yanova E. M., Antipkin Y. G., Arabskaya L. P., Kravchenko S. A., Matsuka G. H., Petit E., Giraudeau F., Guen B. L., Vergnaud G., 1999). In such a situation pursuing simulation experiments supported by the accurate dosimetry on laboratory animals of known physiological behavior and functions is highly motivated.

Purpose - to gain insight into genesis of dose-dependent radiation damage in rat germ cells in order to further elucidate the mechanisms underlying injury and recovery of male germ cells that ensure post-radiation motility and fertility of spermatozoa.

Methods. Laboratory white rats in the age of 3 months were irradiated by gamma rays of ${ }^{60} \mathrm{Co}$ in the dose range $1-18 \mathrm{~Gy}$ with a dose rate $1.0 \mathrm{~Gy} / \mathrm{min}$ in the zone including testicules and lower quarter of the body, the other body parts being shielded by protective cloth containing lead plates of $3 \mathrm{~mm}$ thickness. The absorbed dose was measured by ferum sulfate method using rat phantom. In the pre-radiation and post-radiation periods animals were held in cages under mixed illumination of natural and artificial light (12 hour day / 12 hour night) on dry food and water ad libitum.

Sperm number in testicules was detected by procedure (Blazak W. F., Treinen K. A., Juniewicz P. E., 1993). According to protocol, decapsulated testicules first were chopped, then homogenized for $2 \mathrm{~min}$. at laboratory blenders on maximal speed in solution mixture containing $150 \mathrm{mMol} \mathrm{NaCl}, 3.8 \mathrm{mMol}$ $\mathrm{NaN}_{3}$ and $0.0 \quad 5 \%$ Tryton X-100 (v/v). Testicular homogenate was stored over whole 
day at $5^{\circ} \mathrm{C}$. During this period a number of spermatozoid heads which had remained in solution was counted. It was proved that only spermatids of 17-19 spermiogenesis stages, which are observed during IV-VIII stages of spermatogenic epithelium cycle can resist not only the destroying power of turbulent flows which have appeared upon fast rotation of blenders in water media, but the solubilization of membranes by Triton X-100 too.

Total number of resistant to homogenization spermatids was detected with the help of Goryayev chamber and phase-contrast microscopy Total number of spermatozoa in epididymis was determined in similar way after homogenization of the latter in saline containing $\mathrm{NaN}_{3}$ and Triton X-100.

Daily spermatozoa production by testis was calculated through dividing total number of turbulent-resistant sperm in testicula on the duration of their presence there, which for rats is equal to 6.1 days (Amann R. P., Johnson L., Thompson D. L., Pickett B. W., 1976).

Spermatozoid motility was assessed in a drop of saline smeared on a glass slide at 37 ${ }^{\circ} \mathrm{C}$ under light microscope at magnification $\mathrm{x} 400$. For this purpose spermatozoa were retrieved from vas deferens. Approximately 150 spermatozoa were selected at random for testing. For sperm viability test an aliquot of semen from vas deferens was mixed with equal volume of staining solution containing eosin $(0,25 \%)$ : nigrosine $(10 \%)$ : $\mathrm{NaCl}(0,9 \%)$ (Mamina V. P., 1998).

For morphology examinations suspension of spermatozoa was fixed in $0,2 \%$ $\mathrm{HCOOH}$ and then stained with the mixture $50 \% \mathrm{AgNO}_{3}$ and $0,2 \%$ HCOOC (1:7) at $55-60{ }^{\circ} \mathrm{C}$ for $15-20 \mathrm{~min}$. Then slides were examined at magnifications x1500 under light microscope (Mamina V. P., 1998).

Comparison of data for different donors' groups was made using analysis of variances (Anova) and unpaired Student's t-test with amendment of Bonferroni. Confidence intervals for mean values were identified using t-statistic at $P=0.95$ and standard errors. All statistical tests were two sided and $P<0.05$ was considered statistically significant (Bland M., 2007).

Results. The experiments have shown the absence of any obvious differences in the body mass shifts between control group and gamma-irradiated animals at the post-radiation period since maximum diminution in body weight up to $17 \%$ was noticed at the dose 18 Gy on the $30^{\text {th }}$ week after irradiation.

Testicules proved to be more sensitive to gamma-irradiation if judging by the weight criterion. Thus, their mean mass in gamma-irradiated animals showed gradual abatement in comparison to control both in the time- and dose-dependent manner.

Epididymices in the course of the first week of post-irradiation period decreased by $30 \%$ in mass compared to control at a dose $18 \mathrm{~Gy}$, while for the time intervals of 7 , 15 and 30 weeks the dose curves were almost similar in shape at 12-18 Gy dose span. At 1 Gy and 6 Gy epididymice weighted 18-20\% more than control on the $1^{\text {st }}$ and $7^{\text {th }}$ week post-irradiation, respectively. However further dose elevation caused rapid diminution of epididymices mean weight.

The mean-mass of ventral prostate in contrast to testes and epididymices at a dose $1 \mathrm{~Gy}$ after 15 weeks post-irradiation increased compared to control by $21 \%$ but afterwards showed gradual decrease towards control value over next 15 weeks. The higher doses of irradiation 6-18 Gy caused ventral prostate lessening for all time intervals of post-irradiation period.

The quantity of germ cells along with Sertoli cells were calculated in $4 \mu \mathrm{m}$ testicular cross-sections stained with hematoxylin and eosin. Primarily, the removed testes were fixed in Bouen's solution, dehydrated in alcohol series and then embedded in paraffin (Meistrich M. L., Samuels R. C., 1985).

Gamma-irradiation did not cause any shifts of Sertoli cell amount for 1 Gy. At 6 Gy small abatement of Sertoli cell quantity below 
the control level was seen just after 7 weeks post-irradiation, while in the other time intervals their mean values showed complete recovery. However, dose lifting sequentially to $12 \mathrm{~Gy}$ and $18 \mathrm{~Gy}$ resulted in degeneration of approximately $20 \%$ of Sertoli cells on the $7^{\text {th }}$ week post-irradiation with no recovery in the later term, i.e. 15 and 30 weeks.

The data received corroborate high radioresistance of Sertoli cells, whose $\mathrm{LD}_{50}$ had been determined to be 15-20 Gy. Spermatogonia, especially differentiating ones such as $A_{1}, A_{2}, A_{3}, A_{4}$, In, B, along with preleptotene spermatocytes are considered to be the most radiosensitive germ cells (Clifton D. K., Bremner W.J., 1983; Rowley M. J., Leach D. R., Warner G. A., Heller C. G., 1974). In view of this, their amount significantly fell down already on the $7^{\text {th }}$ day post-irradiation and then partially restored up to control value at the dose of 1 Gy. At 6 Gy recovery of spermatogonia did not exceed $20 \%$ of control whereas the doses 12 Gy and 18 Gy caused their almost complete disappearance from seminiferous epithelium in the post-irradiation period. The later two doses proved to be detrimental also for spermatocytes and spermatids, whose survival did not surpass $7 \%$ over 1 week after gamma-irradiation in the dose $12 \mathrm{~Gy}$.

Thereby, seminiferous tubules showed dose dependent depletion of germ cell stocks inside them with simultaneous preservation of somatic Sertoli cells in sufficient abundance that was favorable for further regeneration of stem spermatogonia (As) and subsequent repopulation of tubules.

Gamma-irradiation of testes by the dose of 1 Gy caused no evident disturbances in total sperm amount (TSA) and daily sperm production (DSP) at $1 \mathrm{~Gy}$. Moreover these parameters slightly exceeded control values after 30 weeks post-irradiation being indicative of a small hormesis effects on spermatogenesis. However higher doses were more detrimental for spermatogenesis resulting in essential depletion of germ cell stocks at 12 and 18 Gy.
Estimation of the epididymal spermatozoa amount found out no radiation effect on this parameter at a dose 1 Gy in the first week post-irradiation while at higher dose range the gradual abatement of the mean spermatozoa contents in epididymis from $131 \times 10^{6}$ at 6 Gy to $1.8 \times 10^{6}$ at 12 Gy and finally to $7 \times 10^{5}$ at 18 Gy was observed. Total sperm counts at 6 Gy over 7-30 weeks were quite low, the viable spermatozoa being in the range $2 \times 10^{2}-$ $2.5 \times 10^{4}$ sperm/epididymis. However, at 12 Gy we noticed some recovery in sperm count for 30 weeks post-irradiation compared to 7-15 week interval. None the less, no viable sperm were found in epididymices of rats 7-30 weeks post-irradiation. At 18 Gy exclusively small amounts of spermatozoa were fully deprived of any viability throughout whole post-irradiation period (Table 1).

The duration of post-irradiation period was shown to have positive influence as on spermatogenesis recovery in testis, as on concomitant surge of epididymal sperm amount along with spermatozoid viability above the control values at the end of $30^{\text {th }}$ week post-irradiation by $1 \mathrm{~Gy}$.

Our observations are in accordance with the results of other authors (Lefevre Y., 1981) who found the dose 0.5 Gy to stimulate sperm production 15 weeks after rat irradiation. Yet, V. Mamina (Mamina V. P., 1998) studied the peculiarities of spermatogenesis in field mice which had been continuously whole body irradiated in natural conditions on the radionuclide polluted territories having accumulating in total radiation dose $0.25-0.75$ Gy. She demonstrated spermatogenesis enhancement and elevation of sperm production in radiation-exposed animals compared to non-irradiated control. Regarding the similar accounts of other authors (Graham C. F., 1974; Yamashiro H., Abe Y., Fukuda T., Kino Ya., Kawaguchi I., Kuwahara Yo., Fukumoto M., Takahashi S., Suzuki M., Kobayashi J., 2013), hormesis effect on animal reproductive system seems to show up regularly under low dose irradiation. 
Analysis of sperm motility has shown its dose-dependent linear decrease to zero after 7 weeks post-irradiation in the dose range 1-6 Gy, while for 30 week sperm motility post-irradiation dose interval expanded to $12 \mathrm{~Gy}$. Over 1 week post irradiation sperm retained their motility up to $18 \mathrm{~Gy}$.

Analysis of sperm morphology revealed the presence of a number of abnormalities in spermatozoa. Notably, insignificant morphologic disturbances were detected also in control. Following the increase in radiation-dose exposure a sudden jump in a quantity of anomalous sperm was found upon passage from $1 \mathrm{~Gy}$ to $6 \mathrm{~Gy}$. Some normal spermatozoa were identified after gamma-irradiation by 6 Gy and 12 Gy. For these doses the amount of sperm abnormalities was growing up in the course of post-irradiation period and reached a peak over 15 week interval. Thereafter sperm abnormalities tended to diminish somehow. However, at 18 Gy neither viable nor normal by morphology sperm were seen.

The further analysis of abnormal sperm types revealed that in control prevailed spermatozoa with cytoplasmic droplets while acrosomeless and with bent heads, or tapered, spermatozoa did not exceed $20 \%$ of all structural disturbances. Meanwhile testes irradiation by the dose of 1 Gy caused evi-

Table 1. The influence of rat testes irradiation by gamma-rays on sperm production and their viability

\begin{tabular}{|c|c|c|c|c|c|}
\hline \multirow{2}{*}{$\begin{array}{c}\text { Parameter, } \\
\text { units }\end{array}$} & \multirow{2}{*}{$\begin{array}{c}\text { Dose, } \\
\text { Gy }\end{array}$} & \multicolumn{4}{|c|}{ Duration of post-irradiation period, weeks } \\
\hline & & 1 & 7 & 15 & 30 \\
\hline \multirow{5}{*}{$\begin{array}{l}\text { Total amount } \\
\text { of } \\
\text { spermatozoa } \\
\text { in testicule, } \\
\times 106 \text { cells }\end{array}$} & Control & $180 \pm 31$ & $222 \pm 24$ & $241 \pm 46$ & $295 \pm 39$ \\
\hline & 1.0 & $177 \pm 25$ & $173 \pm 29$ & $226 \pm 34$ & $301 \pm 44$ \\
\hline & 6.0 & $99 \pm 18$ & $0,0023 \pm 0,0018^{*}$ & $0,099 \pm 0,008^{*}$ & $0,024 \pm 0,007 *$ \\
\hline & 12.0 & $1,39 \pm 0,03 *$ & $0,0015 \pm 0,0009 *$ & $420,0068 \pm 0,0017 *$ & $0,0399 \pm 0,0014$ \\
\hline & 18.0 & $0,54 \pm 0,06^{*}$ & $0,0003 \pm 0,0001 *$ & $0,0011 \pm 0,0007 *$ & $0,0047 \pm 0,0005^{*}$ \\
\hline \multirow{5}{*}{$\begin{array}{l}\text { Daily sperm } \\
\text { production } \\
\text { by testicule, } \\
\times 106 \text { cells }\end{array}$} & Control & $29,6 \pm 0,5$ & $36,4 \pm 0,7$ & $39,5 \pm 0,6$ & $48,3 \pm 0,7$ \\
\hline & 1.0 & $29,0 \pm 0,5$ & $28,4 \pm 0,7$ & $37,0 \pm 0,4$ & $49,3 \pm 0,9$ \\
\hline & 6.0 & $16,2 \pm 0,4$ & $0,0304 \pm 0,00014^{*}$ & $0,016 \pm 0,009 *$ & $0,0040 \pm 0,0008$ \\
\hline & 12.0 & $0,23 \pm 0,07^{*}$ & $0,0002 \pm 0,0001 *$ & $0,0011 \pm 0,0006^{*}$ & $0,0065 \pm 0,0007$ \\
\hline & 18.0 & $0,089 \pm 0,003^{*}$ & $0,00005 \pm 0,00002 *$ & $0,0002 \pm 0,0001^{*}$ & $0,0008 \pm 0,0002$ \\
\hline \multirow{5}{*}{$\begin{array}{l}\text { Total amount } \\
\text { of } \\
\text { spermatozoa } \\
\text { in epididymis, } \\
\times 106 \text { cells }\end{array}$} & Control & $240 \pm 38$ & $295 \pm 44$ & $320 \pm 37$ & $392 \pm 43$ \\
\hline & 1.0 & $235 \pm 41$ & $230 \pm 36$ & $300 \pm 31$ & $400 \pm 62$ \\
\hline & 6.0 & $131 \pm 24^{*}$ & $0,003 \pm 0,001^{*}$ & $0,131 \pm 0,011 *$ & $0,032 \pm 0,0011 *$ \\
\hline & 12.0 & $1,85 \pm 0,19^{*}$ & $0,002 \pm 0,001^{*}$ & $0,009 \pm 0,005^{*}$ & $0,053 \pm 0,009 *$ \\
\hline & 18.0 & $0,72 \pm 0,07^{*}$ & $0,0004 \pm 0,0003^{*}$ & $0,0015 \pm 0,0008^{*}$ & $0,0063 \pm 0,0007$ \\
\hline \multirow{5}{*}{$\begin{array}{l}\text { Total amount } \\
\text { of viable } \\
\text { spermatozoa } \\
\text { in epididymis, } \\
\times 106 \text { cells }\end{array}$} & Control & $223 \pm 33$ & $265 \pm 42$ & $272 \pm 38$ & $349 \pm 47$ \\
\hline & 1.0 & $191 \pm 21$ & $172 \pm 34$ & $235 \pm 37$ & $360 \pm 52$ \\
\hline & 6.0 & $32 \pm 5$ & $0,0002 \pm 0,0001 *$ & $0,0025 \pm 0,0013^{*}$ & $0,0051 \pm 0,0009$ \\
\hline & 12.0 & $0,51 \pm 0,11^{*}$ & $0 *$ & $0 *$ & $0 *$ \\
\hline & 18.0 & $0 *$ & $0 *$ & $0 *$ & $0 *$ \\
\hline
\end{tabular}

Note. ${ }^{*}$ - significant differences with control at $\mathrm{p}<0,05$ 
dent appearing of tailless and acrosomeless sperm, the latter likely having emerged due to spontaneous acrosome reaction up-regulation. Yet, a great deal of spermatozoa with cytoplasmic droplets was detected, especially on $30^{\text {th }}$ week of post-irradiation period.

The further radiation dose elevation resulted in a remarkable expansion of tailless sperm pool which appeared to have formed in the process of axoneme cytoskeleton disintegration through oxidative stress-induced destruction of microfibrils.

In consequence, at 12 Gy only tailless spermatozoa from 7 till 30 week post-irradiation were found whereas for $18 \mathrm{~Gy}$ this phenomenon took place throughout post-irradiation period.

\section{Conclusion}

It was shown that gamma-irradiation of testes by the dose of 1 Gy caused no evident disturbances in total sperm amount (TSA) and daily sperm production (DSP). Moreover these parameters slightly exceed- ed control values after 30 weeks post-irradiation being indicative of a small hormesis effects on spermatogenesis. However higher doses were more detrimental for spermatogenesis resulting in essential depletion of germ cell stocks at 12,0 and 18,0 Gy.

The development of testicules and epididymices was suppressed by the doses higher than 7,0 Gy in the period 7-30 weeks. Concurrently, production of total and viable sperm was very low, abnormal spermatozoa prevailing.

The dose irradiation of 1,0 Gy causes a partial decrease in the number of viable sperm and an increase in morphologically abnormal sperm within the first 15 th weeks after irradiation. At 30 weeks, the formation of viable morphologically normal sperm was recovered. Increasing the dose irradiation from 7,0 Gy to 18,0 Gy causes a sharp decrease in viable sperm at all post-radiation periods, with no viable and morphologically normal sperm at the 18,0 Gy dose.

\section{References}

1. Pomerantseva, M. D., Ramaiya, L. K, Chekhovich, A. V. (1997). Genetic disorders in house mouse germ cells after the Chernobyl catastrophe. Mutation Research, 381, 97-103.

2. Goncharova, R. I., Ryabokon, N. I. (1995). Dynamics of cytogenetic injuries in natural populations of bank vole in the republic of Belarus. Radiation Protection Dosimetry, 62(1-2), 37-40.

3. Hoyes, K. P., Morris, I. D. (1996). Environmental radiation and male reproduction. International Journal of Andrology, 19, 199-204.

4. Miller, S. C., Rowland, H. G., Bowman, B. M. (1985). Distribution of cell populations within alpha-particle range of plutonium deposits in the rat and beagle testis. Radiation Research, 101, 102-10.

5. Preist, N. D., Jackson, S. (1978). The uptake and redistribution of $241 \mathrm{Pu}$ within the gonads. International Journal of Radiation Biology, 34, 49-65.

6. Taylor, D. M. (1993). Transferrin complexes with non-physiologic and toxic metals. In: Perspectives in Bioinorganic Chemistry, Vol. 2. Greenwich CN: JAI Press, 139-159.

7. Pomerantseva, M. D., Ramaya, L. K., Shevchenko, V. A., Vilkina, G. A., Lyaginskaya, A. M. (1989). Evaluation of the genetic effects of 238Pu into mice. Mutation Research, 226, 93-98.

8. Ramaiya, L. K., Pomerantseva, M. D., Chekhovich, A. V., Lyaginskaya, A. M., Kuznetsov, A. S. (1994.) Genetic effects on testicular incorporation of 137-Cs in mice. Mutation Research, 324, 139-45.

9. Demin, J. S., Kryukov, V. I., Orlov, V. N. [Studies of thaplotypes in natural population of house mice]. Genetika. 1980;16(7):1271-6. Russian.

10. Yamashiro H, Abe Y, Fukuda T, Kino Ya, Kawaguchi I, Kuwahara Yo, Fukumoto M, Takahashi S, Suzuki M, Kobayashi J. Effects of radioactive caesium on bull testes after the Fukushima nuclear plant accident. Sci Rep. 2013;3:45-51.

11. Sailer BL, Jost LK, Erikson KR, Tajiran MA, Evenson DP. Effects of X-irradiation on mouse testicular cells and sperm chromatin structure. Environ Mol Mutagen. 1995;25(1):23-30. 
12. Dubrova YE, Jeffreys AJ, Malashenko AM. Mouse minisatellite mutations induced by ionizing radiation. Nat Genet. 1995;5:92-4.

13. Sadamoto S, Suzuki S, Kamiya K, Kominami R, Dohi K, Niwa O. Radiation induction of germline mutation at a hypervariable mouse minisatellite locus. Int J Radiat Biol. 1994;65:549-57.

14. Dubrova YE, Plump M, Brown J, Fennelly J, Bois P, Goodhead D, Jeffreys AJ. Stage specificity, dose response, and doubling dose for mouse minisatellite germ-line mutation induced by acute radiation. Proc Natl Acad Sci U S A. 1998;95:6251-5.

15. Dubrova YE, Plump M, Brown J, Jeffreys AJ. Radiation-induced germline instability at minisatellite loci. Int J Radiat Biol. 1998;74:680-96.

16. Ahmadi A, Ng S-Ch. Fertilization and development of mouse oocytes injected with membrane-damaged spermatozoa. Hum Reprod. 1997;12(12):2797-801.

17. Ahmadi A, Ng S-Ch. Developmental capacity of damage spermatozoa. Hum Reprod. 1999;14(9):2279-85.

18. Jensen TK, Bonde JP, Joffe M. The influence of occupational exposure on male reproductive function. Occupational Medicine-Oxford. 2006;56:544-53.

19. Moller AP, Surai PF, Mousseau TA. Antioxidants, radiation and mutation in barn swallows from Chernobyl. Proc R Soc Lond B. 2005;272:247-53.

20. Bonisoli-Alkuati A, Moller AP, Rudolfsen G, Saino N, Caprioli M, Osterniller Sh, Mousseau TA. The effects of radiation on sperm swimming behavior depend on plasma oxidative status in the barn swallow (Hirundo rustica). Comp Biochem Physiol A Mol Integr Physiol. 2011;159(2):105-12. doi: 10.1016/j.cbpa.2011.01.018.

21. Moller AP, Karadas F, Mousseau TA. Antioxidants in egg of great tits Parus major from Chernobyl and hatching success. J Comp Phys B. 2008;178:735-43.

22. Moller AP, Karadas F, Mousseau TA. Abundance of birds in Fukushima as judged from Chernobyl. Environ Pollut. 2012;164:36-9.

23. Vorobtsova IE. [Genetical and somatic effects in human and animals (comparative aspects)]. Radiat Biol. Radioecology; 2002;42(6):639-43. Russian.

24. Yablokov AV, Nesterenko VB, Nesterenko AV. Chernobyl: consequences of the catastrophe for people and nature. New York: Academy of Sciences, USA; 2009. 400 p.

25. Dubrova YE., Nesterov VN, Krouchinsky NG, Ostapenko VA, Neumann R, Neil DL, Jeffreys AJ. Human minisatellite mutation rate after the Chernobyl accident. Nature. 1996;380:683-6.

26. Dubrova YE, Nesterov VN, Krouchinsky NG, Ostapenko VA, Vergnaud G, Giraudeau F, Buard J, Jeffrey AJ. Further evidence for elevated human minisatellite mutation rate in Belarus eight years after the Chernobyl accident. Mutat Res. 1997;381:267-78.

27. Furistu F, Ryo H, Yeliseeva KG, Thuy ITT, Kawabata H, Krupnova EV, Trusova VD, Rzheutsky VA, Nakajima H, Nomura T. Microsatellite mutations show no increases in the children of the Chernobyl liquidators. Mutat Res. 2005;581:69-82.

28. Kodaira M, Satoh C, Hiyama K, Toyama K. Lack of effects of atomic bomb radiation on genetic instability of tandem-repetitive elements in human germ cells. Am J Hum Genet. 1995;55:1275-83.

29. Livshits LA, Malyarchuk SG, Luk'yanova EM, Antipkin YG, Arabskaya LP, Kravchenko SA, Matsuka GH, Petit E, Giraudeau F, Guen BL, Vergnaud G. Heritable mutations at some minisatellite loci analysis in children of liquidators of Chernobyl accident consequences. Int J Radiat Med. 1999;1:101-6.

30. Blazak WF, Treinen KA, Juniewicz PE. Application of testicular sperm head counts in the assessment of male reproductive toxicity. In: Chapin RE, Heindel JJ, editors. Methods in Toxicology. Vol. 3, Pt. A. Male Reproductive Toxicology. San Diego, California: Academic Press; 1993. p. 86-94.

31. Amann RP, Johnson L, Thompson DL, Pickett BW. Daily spermatozoal production, epididymal spermatozoal reserves and transit time of spermatozoa through the epididymis of the rhesus monkey. Biol Reprod. 1976;15(5):586-92.

32. Mamina VP. [Histological analysis of testes in forest mouse (Apodemus sylvaticus) and red mouse (Clethrionomus rutilus) inhabiting in conditions of higher radiation phone]. Radiat Biol. Radioeology. 1998;38(6):813-8. Russian.

33. Bland M. An introduction to medical statistics. 3rd ed. Oxford: Oxford Univ. Press, 2007; 405 p.

34. Meistrich ML, Samuels RC. Reduction in sperm level after testicular irradiation of the mouse: a comparison with man. Radiat Res. 1985;102:138-47.

35. Clifton DK, Bremner WJ. The effect of testicular x-irradiation on spermatogenesis in man. A comparison with the mouse. J Androl. 1983;4:387-92. 
36. Rowley MJ, Leach DR, Warner GA, Heller CG. Effect of graded doses of ionizing radiation on the human testis. Radiat Res. 1974;59:665-78.

37. Lefevre Y. The distribution of randomly recovered X-ray induced sex-linked genetic effects in Drosophila melanogaster. Genetics. 1981;99(4):461-80.

38. Graham CF. The production of parthenogenetic mammalian embryos and their use in biological research. Biol Rev Camb Philos Soc. 1974;49(3):399-424.

\section{АНОТАЦІЯ}

А. В. Клепко, С. В. Андрейменко, І. М. Гудков. Динаміка розвитку пошкодження та відновлення в органах репродуктивної системи і сперматозоїдах при гамма-опроміненні тварин. Біоресурси і природокористування. 2019. 11, №5-6. C.48-57. https://doi.org/10.31548/bio2019.04.006

Анотаиія. Проведені дослідження спрямовані на вивчення динаміки пошкодження та відновлення чоловічих статевих клітин через тривалий термін після локального опромінення ділянки тазу в залежності від дози іонізуючої радіаиї. Білих лабораторних щурів у вічі 3 місяиі опромінювали гамма-променями 60Со в діапазоні доз 1,0-18,0 Гр з потужністю дози 1,0 Гр/хв. Кількість сперми в яєчках та епідидимітах визначали за допомогою фазово-контрастної мікроскопї після гомогенізачї органів. Щоденну продукиію сперматозоїдів розраховували шляхом ділення загальної кількості турбулентно-стійких сперматозоїдів до час їх знаходження в тестикулах, тобто 6,1 дні. Експерименти показали, що сім'яні канальиі иурів проявляють дозо залежне виснаження статевих клітин в них з одночасним збереженням соматичних клітин Сертолі, шо сприяло подальшій регенераиї стовбурових сперматогоній (As) та репопуляиї сім'яних канальиів. Показано, шо доза 1,0 Гр не спричиняе негативний вплив на розвиток тварин та продукиію сперми, тоді як локальне опромінення в дозах 7,0-12,0 Гр призводить радіачійного ураження статевої системи иурів. Дія іонізуючої радіаиї̈ в дозі 18,0 Гр повністю пригнічує сперматогенез та сперміогенез у сім'яниках лабораторних тварин.

Ключові слова: локальне опромінення, сперматогенез, гермінативні клітини, иури, денна продукиія сперматозӧ̈ів, життєздатність, довготривалий період.

\section{АННОТАЦИЯ}

А. В. Клепко, С. В. Андрейченко, И. М. Гудков. Динамика развития повреждения и восстановления в органах репродуктивной системъ, а также сперматозоидах при гамма-облучении животнъхх. Биоресурсы и природопользование. 2019. 11, №5-6. C.48-57. https://doi.org/ 10.31548/bio2019.04.006

Аннотачия. Проведеннье исследования направлены на изучение динамики повреждения и восстановления мужских половых клеток через длительный период после локального облучения участка таза в зависимости от дозы ионизирующей радиа иии. Бельх лабораторных крыс в возрасте 3 месяиа облучали гамма-лучами 60Со в диапазоне доз 1,018,0Гр примошностидозы 1,0Гр/мин. Количество спермы в яичках и әпидидимисах определяли $c$ помочщъю фазово-контрастной микроскопии после гомогенизачии органов. Дневную продукиию сперматозоидов рассиитьввали путем деления общего количества тербулентно-устойчивых сперматозоидов ко времени их нахождения в тестикулах, ито равно 6,1 дня. Эксперименты показали, что семеннъек канальиы крыс проявляют дозозависимое исто- шение в них половых клеток с одновременным сохранением соматических клеток Сертоли, ито, в свою очередь, способствовало дальнейшей регенераиии стволовых сперматогоний (As) и репопуляиии семенных канальиев. Показано, что доза в 1,0 Гр не оказывает негативного влияния на развитие $и$ продукиию спермы у крыс, тогда как локальное облучение в дозах 7,0-12,0 Гр приводит к радиаиионному повреждению их половой системъ. Действие ионизируюшей радиачии в дозе 18,0 Гр полностью подавляет сперматогенез и спермиогенез в семенниках лабораторных животных.

Ключевые слова: локальное облучение, сперматогенез, герминативные клетки, суточная продукиия сперматозоидов, жизнеспособность, длительнъй период 